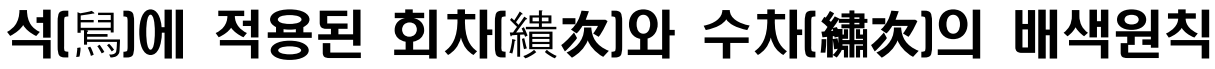

\author{
최 연 우 \\ 단국대학교 전통의상학과 교수
}

\section{Principles of Coloration for Hoecha and Sucha Applied to Seok}

\author{
Yeon-Woo Choi \\ Professor, Dept. of Korean Traditional Costume, Dankook University \\ (투고일: 2014. 5. 7, 심사(수정)일: 2014. 5. 13, 게재확정일: 2014. 7. 30)
}

\begin{abstract}
This paper examines the way that the principles of coloration for Hoecha(繢次; 繪次) and Sucha(紼次) were applied for shoe making in ancient China and Korea. Hoecha is the principle of drawing, and Sucha is the principle of embroidery. Hoecha and Sucha is the application principle of the five colors(五方色) from the five elements(五行: metal, wood, water, fire, and earth). Hoecha matchs a color with the opposite side color, and Sucha matchs a color with the beside color. A shoe consists of Sinul(body of shoe) and ornaments attached to it. According to the ratings of shoes, Hoecha and Sucha were differently applied for coloration of Sinul and its ornaments. In general, shoes were classified into Seok(舄) and $G u($ 履). For Seok, which was the high-ranked shoes, Hoecha was applied, while Sucha was applied to $G u$, the low ranked shoe. As Hoecha was originally a principle of coloration for patterns on tops(jacket. 上衣), it was applied to the high ranked shoes i.e., Seok. Also, as Sucha was a principle of coloration for patterns on bottoms(skirt. 下裳), it was applied to the low ranked shoes i.e., $G u$. Thus, black was decorated on red Seok, blue on white Seok, red on black Seok, yellow on hyeon(玄: a kind of black color) Seok, and white on blue Seok, all of which were applications of the principle of Hoecha. As the application of the principle of Hoecha to Seok was also done for red Seok for males and females in late Joseon, and red Seok for the crown prince in the period of the Korean Empire, black decorations were used for red Sinul. However, for blue Seok, worn by females in the period of the Korean Empire where Ming's systems prevailed, black decorations were used, which was an application of Sucha. Though there had been no discrimination between genders in the application of Hoecha and Sucha originally, the low ranked principle of coloration was applied to Seok for females.
\end{abstract}

Key words: Hoecha(繢次; 繪次: the principle of drawing), Jeik-ui(翟衣), Myeon-bok(冕服),

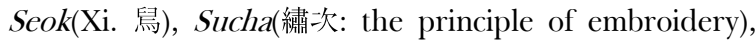

the five elements(五行: metal, wood, water, fire, and earth)

이 연구는 2013학년도 단국대학교 대학연구비 지원으로 연구되었음.

Corresponding author: Yeon-woo Choi, e-mail: ywchoi@dankook.ac.kr 


\section{I . 머리말}

조선의 전례서(典禮書)인 『국조오례의(國朝五禮 儀)』의 '전하면복(殿下冕服)'에는 상의(上衣)와 하상 (下裳)에 표현하는 무늬에 관해 “그림을 그리는 것 [繪]은 양(陽)의 일이므로 상의에 있고, 자수를 놓는 것[繡]은 음(陰)의 일이므로 하상에 있다.”1)라는 내 용이 있다. 위[上]는 양에 해당하고 아래[下]는 음에 해당하므로, 무늬를 표현할 때 상의에는 양을 상징하 는 그림으로 그리고 하상에는 음을 상징하는 자수를 놓는다는 원칙을 명시한 것이다. 그런데 후술하겠지 만, 면복에 그림과 자수로 무늬를 표현할 때는 배색 에 있어 원칙 없이 임의로 색을 쓰는 것이 아니라 그림과 자수 각각에 적용하는 원칙이 있다. 그리고 이 원칙은 상의와 하상에 무늬를 표현할 때 뿐만 아 니라 예복에 신는 신에도 적용된다. 특히 신 중에서 남녀가 최고 등급의 예복에 신는 석(舄)에는 중국뿐 만 아니라 우리나라의 대한제국시대까지도 영향을 미친다.

지금까지 석에 관해서는 크게 신에 관한 전반적인 연구, 남자와 여자 예복 즉 면복과 적의 연구, 의례 복 즉 혼례복이나 제례복에 관한 연구 등에서 일부 다루어졌다. 그러나 그 내용이 매우 소략하여 시대와 남녀에 따른 형태 차이 등 기본적인 내용도 본격적 으로 연구가 이루어지지 않았었고, 특히 본고에서 다 룰 배색원칙에 관해서는 전혀 고찰된 적이 없었다. 이에 필자는 우리나라 석의 형태와 특징 등에 관한 전반적인 고찰을 염두에 두고 총3편으로 나눠 연구 를 진행하고 있다. 본고는 그 마지막 연구이다. 앞서 2 편의 선행연구에서 조선시대와 대한제국시대의 착 용신분 및 착용상황, 종류와 형태, 명칭, 장식 등에 관해 남녀로 나눠 각각 살핀 후, 이를 바탕으로 한국 석의 특징을 추출하고 그 유래에 관해 살폈다.2) 본 논문은 석의 신울과 장식에 적용된 배색원칙에 관한 고찰을 연구목적으로 한다.

연구내용은 크게 두 부분으로 이루어진다. 먼저, 고대의 예서(禮書)에 제시된 배색원칙인 회차(繢次) 와 수차(繡次)에 관해 고찰한다. 회차와 수차는 지금 까지 복식사뿐만 아니라 그 원리와 밀접하게 관련되
는 미술사나 색채사학계에서도 전혀 소개되지 않은 이론이므로, 그 기본원리 및 상징 등에 관해 상세히 살피게 될 것이다. 이어, 선행연구에서 고찰한 내용 을 바탕으로 남녀로 나눠 한국 석에 나타나는 신울 과 장식간의 배색을 정리하고, 그 배색에 회차와 수 차의 원칙이 준용된 정도와 변용된 양상에 관해 고 찰한다.

연구는 문헌 내용을 세밀히 분석하는 방법 위주로 진행하고자 한다. 회차와 수차의 원칙은 고례서(古禮 書)인『주례』와『의례』에 상세히 기록되는데, 그 원 리 및 상징을 소개하는 것이 본고의 일차적인 목적 이므로 문헌 내용을 이론적으로 면밀히 분석하는 것 이 연구목적 달성을 위한 가장 효과적인 방법이다.

본고에서 고찰할 회차와 수차의 원칙은 동아시아 철학의 주축이 되는 천지(天地)와 오행(五行)을 운 용한 이론으로, 오행의 상생(相生), 상극(相剋)과 더 불어 매우 주목할 만한 이론이다. 그러나 지금까지 복식사학계는 물론 색채사학이나 미술사학 등 기타 학계에서 전혀 주목되지 않았다. 따라서 본고는 천지 와 오행의 운용 및 복식에의 적용에 관한 이론을 소 개하여 전통복식 및 전통문화의 이해에 보다 풍부한 시각을 제시할 수 있다는 점에서 의의가 있다. 또 본 고까지 총3편으로 나눠 진행한 연구를 통해 형태와 배색 등에 나타나는 한국 석의 특징을 종합적으로 규명한다는 점에 연구의의가 있다.

\section{II. 회차와 수차의 배색원칙}

\section{1. 고대 신의 종류와 구조}

\section{1) 신의 종류: 석(舄)과 구(屨)}

흔히 신목이 없이 신울만 있는 신을 통칭하는 한 자로 혜(鞋)를 쓴다. 그러나 '혜'가 신의 통칭이 된 것은 대략 수당(隋唐)시대에 이르러서이고, 그 이전 에는 리(履)가 신의 통칭이었다. 또 '리'는 대략 전국 시대(戰國時代) 이전까지는 동사 '밟다(踏)'의 의미 로 주로 쓰이고, 신의 통칭으로 주로 쓰인 것은 전국 시대 이후의 일이다. 전국시대 이전에 신의 통칭은 구(屩)였다. ${ }^{3)}$ 즉 신의 통칭은 구-리-혜로 변천해 온 
것이다. 그런데 '구'는 신의 통칭이기도 하지만, 신을 크게 두 등급으로 나눴을 때 하위 등급의 신을 의미 하기도 한다.

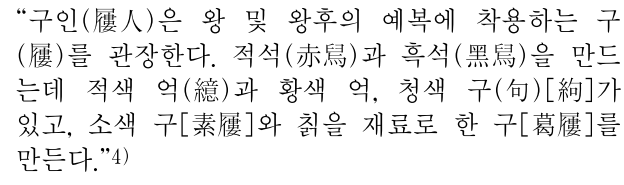
(㞜)를 관장한다. 적석(赤舄)과 흑석(黑舄)을 만드 는데 적색 억(繶)과 황색 억, 청색 구(句)[絇]가 있고, 소색 구[素屨]와 칡을 재료로 한 구[葛偖]를 만든다." ${ }^{4}$

『주례』r구인(嫂人)」의 내용이다. 구인은 궁중의 신에 관한 일을 관장하던 관직이고, $\mathrm{r}$ 구인,편에서는 그들이 담당하는 직책을 서술한다. 위 내용은 구인 관직이 천자인 왕과 그 배우자인 왕후의 예복에 착 용하는 신을 전반적으로 관장한다는 것을 명시한다. 그리고 신의 통칭으로 '구'를 말하였고, 그 아래에 다 시 석(舄)과 구가 있다는 것을 말하였다. 이를 통해 '구'는 광의와 협의의 의미가 있음이 파악된다. 광의 로는 신의 통칭이고, 협의로는 석과 구별되는 별도의 신이다.

그렇다면 석과 협의의 구(이하에서 '구'라 하면 협 의의 구를 말함)는 무슨 차이가 있는가? 위 경문에 대해 한대(漢代)의 주석가(注釋家)인 정현(鄭玄: 127-200년)과 당대(唐代)의 주석가인 가공언(賈公 彥: ?-?년)은 아래와 같이 주석하였다.

정현 주(注): “아래[下]를 겹[復]으로 한 것을 석 (舄)이라 하고, 아래를 홑으로 한 것을 구(嵋)라 한다."

가공언 소(疏): “'아래[下]'는 바닥[底]을 말하고 '겹[復]'은 이중바닥을 말한다. 바닥을 이중으로 한 것은 '석'이라 하고, 바닥을 홑으로 한 것은 '구'라 한다." ${ }^{\prime \prime}$

또 『방언 $($ 方言 $) 』$ 과『고금주 $($ 古今注 $) 』$ 에는 아래의 내용이 있다.

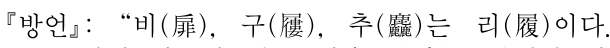
……중간에 나무가 있는 것은 복석(復舄)이라 하 는데, 관동(關東)에서는 ‘복리(復履)'라 한다.”6)

『고금주』: “석은 나무를 리(履)의 아랫부분에 댄 것으로, 건조하게 하여 진흙과 습기가 올라오지 못 하게 한다."7)
위 내용을 종합하면, 신 중에서 바닥을 이중으로 해서 그 사이에 나무를 대면 '석'이라 하고, 바닥을 홑으로 하면 '구’라 한 것을 알 수 있다.

이렇게 석과 구로 대별되는 신울이 없는 신은 다 시 예복의 등급에 따라 여러 종류가 있다. 그 세부 종류는 신울과 장식의 배색을 고찰할 때 다시 언급 하는 것이 이해에 도움이 되므로 다음 절에서 상세 히 살핀다.

\section{2) 신의 구조}

위에서 본 것처럼 석과 구는 겹바닥인지 혹은 홑 바닥인지의 여부로 구분하지만, 다른 구조는 같다. 즉 석과 구 모두 신의 몸체인 신울이 있고, 여기에 장식인 구(絇; 句), 억(繶), 준(純), 기(綦) 등이 붙 여져〈그림 1〉8)과 같은 형태가 된다. 위에서 인용한 『주례』r구인」의 경문에 대한 주석에서 정현과 가공 언은 아래와 같이 말한다.

정현 주: “석(舄)과 구(㞛)는 구(絇), 억(繶), 준 (純)이 있는데, 장식이다."

가공언 소: “억(繶)은 신울과 신바닥이 서로 만나 는 곳의 솔기 그 가운데에 끈목[條]을 붙인 것이 다. 구(絇)는 신의 앞머리에 끈목으로 코를 만든 것이다. 준(純)은 끈목으로 신 입구에 가선을 만든 것이다." ${ }^{9)}$

신울 외에 구, 억, 준의 장식이 있는데, 모두 끈목 [條]으로 만드는 것을 알 수 있다. 또 이들 장식의 위치도 파악된다. 구는 앞쪽 중앙에 있는 신코이고, 중앙에 구멍이 나도록 동그랗게 만든다. 착장자의 행 동을 구속(拘束)하여 경계하는 마음을 갖게 한다는 의미를 내포한다.10) 억은 신울과 신창을 꿰맨 솔기 위에 붙이는 끈목이다. 준은 신 입구 가장자리에 두 르는 가선이다.

한편 신의 장식은 구, 억, 준 외에 기(棊)가 있다. 기는 신의 뒷꿈치에 다는 끈이다. 신을 신을 때, 이 끈의 양쪽 끝을 앞으로 보내 구에 관통시킨 후 발 등에서 묶는다.11) 


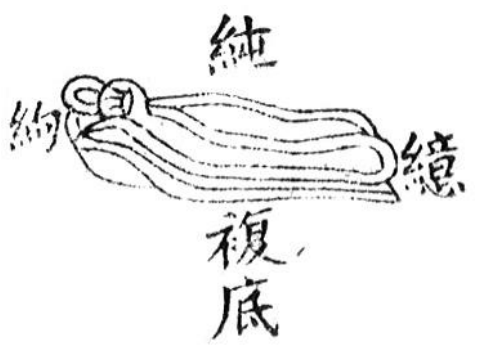

〈그림 1〉신의 구조

- 儀禮圖.

\section{2. 신의 종류에 따른 회차와 수차의 적용 및 예외}

위에서 신목이 없이 신울만 있는 신은 크게 바닥 의 형태에 따라 석과 구로 대별되고, 이 석과 구는 예복에 따라 종류를 세분할 수 있다고 했다. 이제 석 과 구의 세부 종류 및 여기에 적용되는 회차와 수차 의 배색에 관해 살핀다.

앞서 인용했던 『주례』「구인(㞜人)」의 경문과 이 에 대한 정현의 주석을 보자.

“구인(屨人)은 왕 및 왕후의 예복에 착용하는 구 (侯)를 관장한다. 적석(赤舄)과 흑석(黑舄)을 만드 는데 적색 억(繶)과 황색 억, 청색 구(句)[絇]가 있고, 소색 구[素侥]와 칡을 재료로 한 구[葛侥]를 만든다."

정현 주(注): “왕(王)의 길복(吉服)은 9 가지가 있 고, 석은 3 등급이 있다. 적석(赤舄)이 상등(上等)인 데, 면복에 신는 석이다. ……아래등급에 백석(白 舄)과 흑석(黑舄)이 있다. 왕후(王后)의 길복은 6 가지가 있고, 제복(祭服)에만 석을 신는다. 현석(玄 舄)이 상등인데, 휘의(褘衣)에 신는 석이다. 아래등 급에 청석(靑舄)과 적석이 있다. 국의(鞠衣) 이하 에는 모두 구(侥)를 신을 뿐이다.

'구(句)'는 마땅히 '구(絇)'로 적어야 하는데, 발음 이 유사하여 오기(誤記)가 생긴 것이다. 구(絇) 억, 준은 같은 색으로 하는데, 여기서 '적색 억, 황 색 억, 청색 구라 한 것은 호언(互言)12)을 섞어 말한 것이다. 석과 구(猸)가 여러 개이므로 돌이켜 서 다시 드러내는 것이다.

모든 석의 장식은 회차(繢次)와 같게 한다. 적색 억은 왕의 흑석의 장식이고, 황색 억은 왕후의 현 석의 장식이며, 청색 구(絇)는 왕의 백석의 장식이 다. '억'을 말하면 반드시 구(絇)와 준이 있고, '구 (絇)'를 말하면 또 억과 준이 있어서, 삼자(三者 구, 억, 준)는 서로 동반되는 것이다. 왕 및 왕후의 적석은 모두 흑색으로 장식하고, 왕후의 청석은 백
색으로 장식한다.

모든 구(屦)의 장식은 수차(紼次)와 같게 한다. 황 구(黃屠)는 백색으로 장식하고, 백구(白霋)는 흑색 으로 장식하며, 흑구(黑猸)는 청색으로 장식한다. 천자와 제후는 길례(吉禮)에 모두 석을 착용하고, 그 나머지 신분은 면복을 입거나 적문(翟紋)이 들 어간 옷을 입을 때만 석을 착용할 뿐이다. 사(士) 는 작변복에 훈구(緟嘚)를 신는데, 흑색으로 구 (絇), 억, 준을 장식한다. 제복에 신는 구(屠)를 높 여서 회차를 따른 것이다."13)

위 내용에서 남녀별 석과 구의 세부 종류 및 등차, 배색 등에 관한 규정이 나타난다. 이를 정리하면 아 래와 같다.

왕(천자)의 길복(吉服)은 대구면(大裘冕), 곤면 (衰冕), 별면(驚冕), 취면(㲎冕), 치면(希冕; 絺冕), 현면(玄冕)의 육면복(六冕服)과 위변복(韋弁服), 피 변복(皮弁服), 관변복(冠弁服)의 삼변복(三弁服) 등 총9가지가 있다.14) 왕후의 길복은 휘의(褘衣), 요적 (揄狄) [搖翟], 궐적(關狄; 屈狄), 국의(鞠衣), 전의 (展衣; 襢衣), 단의(緣衣; 䙩衣)의 6 가지가 있는데, 이 중 앞의 세 옷은 모두 제복으로 착용하였고 적문 (狄紋)[翟紋]이 들어가기 때문에 한대에 '삼적(三翟)' 이라 하였다.15)

왕과 왕후의 예복은 각 종류에 따라 석과 구를 차 별화해서 신는다. 왕의 석은 적석, 백석, 흑석이 있다. 여기서 '적석', '백석' 등의 명칭은 신울의 색을 기준 으로 한다. 적석은 신울이 적색이고, 백석은 신울이 백색이며, 흑석은 신울이 흑색이다. 왕은 9 가지 예복 에 모두 석을 쓰는데 면복에는 적석, 위변복과 피변 복에는 백석, 관변복에는 흑석이다. 왕후의 석은 현 석(玄舄),16) 청석, 적석이 있다. 예복 중 적문이 있는 삼적에만 석을 쓰는데 휘의에 현석, 요적에 청석, 궐 적에 적석이다. 왕후의 구는 황구, 백구, 흑구가 있다. 황구는 국의, 백구는 전의, 흑구는 단의에 신는다. 왕 후의 석과 구는 모두 예복의 색을 따른 것으로, 휘의 는 현색, 요적은 청색, 궐적은 적색, 국의는 황색, 전 의는 백색, 단의는 흑색이다. ${ }^{17)}$

이상의 내용을 통해 석은 구보다 높은 등급의 신 으로, 중요한 예복에 착용한다는 점이 확인된다.

한편 왕과 왕후의 길복 중 일부는 다른 신분도 착 용할 수 있다. 대구면은 왕만 입지만, 곤면복부터 관 
변복까지는 제후 이하 대부까지 신분에 따라 종류를 차별화하여 착용할 수 있다. 또 휘의는 왕후만 입지 만, 요적부터 단의까지는 기타 내외명부가 신분에 따 라 종류를 차별화하여 착용할 수 있다. 그러나 석의 사용에 있어 왕은 예복에 모두 석을 신고 이는 같은 군주 신분인 제후도 마찬가지이지만, 기타 신분은 면 복에만 석을 신고 나머지 옷에는 구를 신는다. 즉 천 자와 제후는 위변복, 피변복, 관변복에도 석을 신지 만, 그 아래 신분은 이들 옷에 석이 아닌 구를 신는 다. 여자용 예복에서는 왕후가 적문이 들어간 옷을 입을 때만 석을 신고 나머지 옷에는 구를 신는데, 다 른 신분도 적문이 들어간 옷에 석을 신고 나머지 옷 에 구를 신는다.

천자와 제후를 제외한 아래 신분이 변복(弁服)에 석이 아닌 구를 신는 상황은 『의례』「사관례」에서도 보인다.

\footnotetext{
“현단(玄端)에는 흑색 구(猸)를 신고, 청색으로 구 (絇), 억(繶), 준(純)을 장식한다. ……소적(素積) 에는 백색 구를 신고, ……치색(緇色: 검은색)으로 구, 억, 준을 장식한다. 작변복(爵弁服)에는 훈색 (緟色: 붉은색) 구를 신고, 흑색으로 구, 억, 준을 장식한다."18
}

사(士) 신분이 관례를 행할 때 초가(初加)에 현단 복(玄端服)을 입는데 그 신은 흑구(黑履)를 신고, 재 가(再加)에 피변복을 입는데 신은 백구(白偖)를 신 으며, 삼가(三加)에 작변복(䨖弁服)을 입는데 신은 훈구(緟㞜)를 신는다는 예법을 명시한 것이다. 훈색 (緟色) 은 붉은색을 의미한다.

이상과 같이 석에는 적석, 백석, 흑석, 현석, 청석 이 있고, 구에는 황구, 백구, 흑구, 훈구가 있다. 그런 데 위에서 인용한 내용들을 보면 신의 배색에 있어 두 가지 특징이 눈에 띈다. 하나는 구(絇), 억, 준 등 의 장식을 모두 같은 색으로 한다는 점이다. 다른 하 나는 석과 구(㞜)의 신울과 장식간의 배색에는 각기 다른 원칙이 적용된다는 점이다. 여기서 회차(繢次) 와 수차(繡次) 가 등장한다.

회차와 수차에 관해서는 위 r구인」 경문에 대한 정현의 주석에서 비교적 상세히 파악된다. 그 내용에 의하면 석에는 회차의 원칙으로 배색을 한다. 적석에
는 흑색, 백석에는 청색, 흑석에는 적색, 현석에는 황 색, 청석에는 백색을 써서 장식을 하는 것이다. 이에 비해 구에는 수차의 원칙으로 배색을 한다. 황구에는 백색, 백구에는 흑색, 흑구에는 청색을 써서 장식을 하는 것이다〈표 1〉. 이 배색원칙에서 남녀에 따른 차 별은 보이지 않는다. 예를 들어, 남자는 회차의 원칙 을 적용하고 여자는 수차의 원칙을 적용하는 등의 차별은 보이지 않는 것이다.

한편 정현의 주석에서는 구에 수차를 적용하는 것 이 기본임을 밝히면서 예외적으로 작변복에 신는 훈 구는 회차를 적용한다고 하였다. 이는 앞에 인용한 r 사관례」 경문에 대한 정현과 가공언의 아래와 같은 주석에서도 확인된다.

정현 주(注): “작변복의 구(嵋)는 흑색으로 장식 한다. 작변복은 존귀하기 때문에 그 구의 장식은 회차(繢次)에 따른다."

가공언 소(疏): “위에서 흑구에 청색으로 구, 억, 준을 장식하고, 백구에 흑색으로 구, 억, 준을 장식 한다고 했는데, 백색과 흑색, 흑색과 청색은 수차 (紼-欠冫)의 일이다. 여기서의 원칙에서는 작변복에 훈구를 쓴다고 했다. 훈색은 남방의 색인 적색을 말하는데, 서방의 백색으로 구, 억, 준을 장식하지 않고 북방의 흑색으로 구, 억, 준을 장식하는 것은 반대방향[對方]끼리 배색한다는 회차(繢次)를 취 하여 장식한 것이다. 석의 배색과 같은 것인데, 작 변복이 제복(祭服)인 것을 존귀하게 여겼기 때문 에 그 장식을 석과 같게 한 것이다."19)

회차는 오방색에서 반대방향[對方]에 있는 색끼리 배색하는 것이고, 때문에 남방 붉은색의 반대방향에 있는 북방 흑색으로 장식한다고 하였다. 또 작변복의 신에 회차를 적용하는 것은 석의 배색원칙과 같은 것이고, 이는 제복으로 착용하는 작변복을 존귀하게 생각하여 높이기 위한 것임을 말하였다. 이에 비해 현단복과 피변복에 신는 흑구와 백구에 각각 청색과 흑색으로 장식하는 것은 수차의 원칙임도 말하였다.

면복은 본래 대부까지만 입고 그 아래의 신분인 사는 입을 수 없다. 사가 착용할 수 있는 최고 등급 의 옷은 작변복이고, 따라서 제례를 행할 때 사는 작 변복을 입는다. 작변복에는 본래 구를 신고, 원래의 원칙대로라면 구에는 수차가 적용되어야 한다. 작변 복에 신는 훈색(붉은색) 구에 수차를 적용하면 흑색 
〈표 1〉왕(천자)과 왕후의 예복별 신의 종류 및 배색

\begin{tabular}{|c|c|c|c|c|c|}
\hline 신분 & 연번 & 예복 & 신 & 배색 & 배색 원 칙 \\
\hline \multirow{9}{*}{$\begin{array}{c}\text { 왕 } \\
\text { (천자) }\end{array}$} & 1 & 大雸冕 & \multirow{6}{*}{ 赤舄 } & \multirow{6}{*}{ 흑색 } & \multirow{9}{*}{ 繢次 } \\
\hline & 2 & 衰冕 & & & \\
\hline & 3 & 驚冕 & & & \\
\hline & 4 & 㲎冕 & & & \\
\hline & 5 & 希冕[絺冕] & & & \\
\hline & 6 & 玄冕 & & & \\
\hline & 7 & 韋弁 & \multirow{2}{*}{ 白舄 } & \multirow{2}{*}{ 청 색 } & \\
\hline & 8 & 皮弁 & & & \\
\hline & 9 & 冠弁 & 黑舄 & 적색 & \\
\hline \multirow{6}{*}{ 왕후 } & 1 & 禕衣（玄衣） & 玄舄 & 황색 & \multirow{3}{*}{ 繢次 } \\
\hline & 2 & 揄狄（青衣） & 靑舄 & 백색 & \\
\hline & 3 & 關狄（赤衣） & 赤舄 & 흑색 & \\
\hline & 4 & 鞠衣（黃衣） & 黃屢 & 백색 & \multirow{3}{*}{ 繡次 } \\
\hline & 5 & 展衣[襢衣]（白衣） & 白㕍 & 흑색 & \\
\hline & 6 & 緣衣[襣衣］（黑衣） & 黑侥 & 청색 & \\
\hline
\end{tabular}

으로 장식하면 안되지만, 이 훈구는 예외적으로 석과 같은 회차의 원칙을 적용하여 흑색으로 장식하는 것 이다. 그 이유는 사의 작변복은 제복으로 입는 것이 므로, 제복을 존귀하게 여긴다는 관념이 반영되었기 때문이다.

여기서 신의 종류에 따라 회차와 수차를 차별화하 여 적용하는 것이 확인된다. 또 존귀한 신은 회차를 적용한다는 것도 확인된다. 그렇다면 현단복과 피변 복의 흑구와 백구에 적용되는 수차는 등급상 회차보 다 낮은 단계에 적용되는 원칙인 것도 파악된다.

\section{3. 회차와 수차의 기본원리 및 상징}

위에서 석과 구의 배색에 각기 회차와 수차가 적 용된다는 점과 구체적인 배색이 어떻게 이루어지는 가를 살펴보았다. 그런데 정작 회차와 수차의 기본원 리가 무엇이고, 석과 구의 배색이 왜 위와 같이 되는 가에 관해서는 파악할 수 없었다. 아래에서는 회차와 수차의 기본원리를 살핀다.

먼저 회차와 수차의 개념을 보자.

회차(繢次)의 “繢”는 본래 '궤”로 읽는다. 그러나 여 기서는 '회'로 읽는데, '그리다'라는 의미의 '회(繪)'와
같은 뜻이고 ‘회(會)’로도 쓴다.20)『주례』에는 $r$ 화회 (畫繢)」 관직이 있다. 그림을 그리는 일을 담당하는 관직으로, '화회(畫繪)'로도 쓸 수 있다. 오늘날에는 '그림'이라는 뜻의 한자어로 '회화(繪畫)'를 쓰지만, 엄격히 분류하면 '회(繪)'와 '화(畫)'는 서로 다른 공 정을 뜻하는 한자이다. 그림을 그리기 위해서는 먼저 선으로 밑그림을 그려야 하고, 이어 그 위에 색을 써 서 그림을 완성한다. 선으로 밑그림을 그리는 것은 ‘화(畫)'라 하고, 색을 쓰는 것은 '회(繪)[繢]’라 한 다.21) 조선시대 도화서(圖畫署)에서 왕실 그림을 그 리던 화원(家圓)이 선화(善畫: 종6품), 선회(善繪: 종7품), 화사(畫史: 종8품), 회사(繪史: 종9품)22) 등 으로 구분된 것도 이런 이유에서였을 것이다. 이렇게 그림을 그릴 때 색을 배치하는 원칙이 바로 회차이 다. 한편 화회 관직은 그림을 그리는 일 뿐만 아니라 자수(刺繡)를 놓는 일도 담당하였는데, 자수를 놓기 위해서는 선으로 밑그림을 그려야하기 때문이다.23) 자수를 놓을 때 색을 배치하는 원칙이 바로 수차이다.

회차와 수차의 기본원리는 $r$ 화회」의 아래내용에서 확인된다. 
(1)경문(經文): “화회의 일은 오색을 섞은 것이다. 동방은 청색이고, 남방은 적색이고, 서방은 백색이 고, 북방은 흑색이다. 천(天)은 현색이고, 지(地)는 황색이다. 청색과 백색을 서로 배색하고, 적색과 흑 색을 서로 배색하며, 현색과 황색을 서로 배색한다."

정현 주(注): “이 내용은 화회가 쓰는 6 가지 색이 상징하는 것과 색을 배치하는 것의 순서를 말한 것으로, 그림으로 그려서 상의(上衣)를 만든다."

가공언 소(疏): “新(繢)”라고 한 것은 대방(對方) 을 들어서 말한 것으로, '동방'이하의 내용이 이것 이다. …...'청색과 백색을 서로 배색한다' 이하는 상의에 그림으로 표현하는 것을 말한 것으로, 대방 의 원칙을 정한 것이다."24)

(2)경문(經文): “청색과 적색을 배색한 것을 문 (文)이라 하고, 적색과 백색을 배색한 것을 장(章) 이라 하고, 백색과 흑색을 배색한 것을 보(䊇)라 하고, 흑색과 청색을 배색한 것을 불(栊)이라 한다. 오채(五彩)를 다 갖춘 것을 수(紼)라 한다."

정현 주(注): “이 내용은 자수를 놓을 때의 색의 사용을 말한 것으로, 자수를 놓아 하상(下裳)을 만 든다.”
가공언 소(疏): “이 경문은 모두 비방(比方)의 색 으로 자수를 놓는 원칙을 말한 것이다."25)

앞서 「사관례」의 가공언 소(疏)에서 회차의 원칙 을 말하면서 반대방향 즉 대방(對方)의 색끼리 배색 한다는 점을 언급하였다. 위 $r$ 화회」 내용을 통해 대 방이란 천지(天地)의 색과 오방(五方)의 색에서 서 로 반대되는 방향이라는 의미임을 알 수 있다. 천 (天)을 상징하는 색은 현색이고 그 대방인 지(地)를 상징하는 색은 황색이다. 또 오방색에서 동쪽 청색의 대방색은 서쪽 백색이고, 남쪽 적색의 대방색은 북쪽 흑색이다. 때문에 회차 곧 대방의 색을 적용하는 석 에서는 적색에 흑색, 백색에 청색, 현색에 황색으로 배색하는 것이다.

이에 비해 수차의 원칙에서는 옆에 있는 방향 즉 비방(比方)의 색끼리 배색한다. 오방색에서 동방 청 색의 비방색은 남방 적색, 남방 적색의 비방색은 서 방 백색, 서방 백색의 비방색은 북방 흑색, 북방 흑

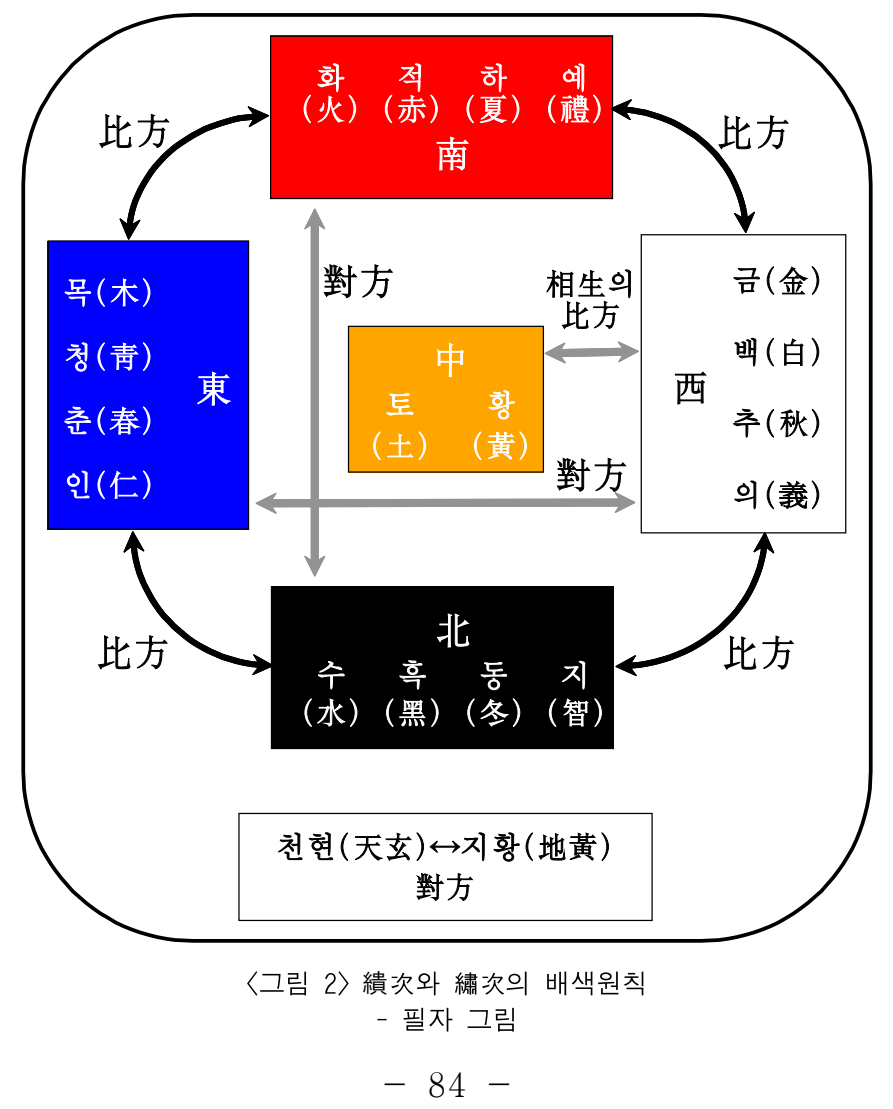


색의 비방색은 동방 청색이다. 때문에 수차 곧 비방 의 색을 적용하는 구에서 백색에 치색(검은색) 혹은 흑색, 흑색에 청색을 배색한 것이다. 또 상생 (相生) 의 관념을 적용시켜서 보면, 상생이 목생화(木生火), 화생토(火生土), 토생금(土生金), 금생수(金生水), 수 생목(水生木)이므로 청-적, 적-황, 황-백, 백-흑, 흑청이 상생하는 색이다. 여자용 황색 구에 백색 장식 을 하는 것은 상생의 색 역시 비방의 색으로 인식된 결과임을 알 수 있다.

이상의 대방과 비방의 배색은 〈그림 2〉에 도식으 로 정리하였다.

그런데 머리말에서 언급한 것처럼 회차와 수차는 본래 면복의 상의와 하상에 12 장문을 표현하기 위해 그림을 그리고 자수를 놓을 때의 배색원칙이다. 상의 에 무늬를 표현할 때는 그림을 그리고 하상에 무늬 를 표현할 때는 자수를 놓는데, 그림을 그릴 때 회차 의 방식을 적용하고 자수를 놓을 때 수차의 방식을 적용하는 것이다.

상의에 그림을 적용하는 것은 그림이 양(陽)을 상 징하기 때문이고 하상에 자수를 적용하는 것은 자수 가 음(陰)을 상징하기 때문이다. 즉 오행에서 상(上) 은 천(天)-양(陽)의 관념과 연계되고, 하(下)는 지 (地)-음(陰)의 관념과 연계되는데, 상의의 무늬를 그 림으로 표현해서 양을 상징하게 하고 하상의 무늬를 자수로 표현해서 음을 상징하게 한다.26)

위 원리는 석에도 그대로 적용된다. 여러 신 중에 서 제복에 착용하는 석과 사(士)가 제례에 착용하는 훈구는 존귀하므로 다른 신보다 높은[上] 위치에 있 다. 때문에 상의의 배색원칙인 회차의 방식을 적용하 여 양의 상징성을 갖게 한 것이다. 이에 반해 구(侥) 는 석보다 아래등급[下]의 신이므로 하상의 배색원 칙인 수차의 방식을 적용하여 음의 상징성을 갖게 한 것이다. 석과 구의 등급에 따른 차별에 더하여 신 울과 장식간의 배색에 양과 음의 상징을 함유시킴으 로써 구와 차별화되는 석의 존귀함을 더욱 강조하고 있다.

\section{III. 한국 석에서의 회차와 수차의 준용과 변용}

우리나라 석 제도의 이론적 근간이 되는 중국 고 대 예서에서는 신을 석(舄)과 구(嫂)로 대별하여 예 복의 등급에 따라 차별화하여 착용하게 했지만, 우리 나라에서는 문헌을 통해 구체적인 제도를 확인할 수 있는 고려시대 이래 주로 석에 관한 제도가 나타난 다. 본 장(章)에서는 우리나라 석의 배색에 관해 고 찰하여 고례서에 제시된 회차와 수차의 준용과 변용 양상을 파악한다.

\section{1. 남자용}

우리나라의 사료 중 석의 배색을 확인할 수 있는 자료는 고려시대부터 나타난다. 고려시대에는 정종 9 년(1043)부터 강종원년(1212)까지 거란, 송(宋), 요 (遼), 금(金), 명(明)에서 고려왕에게 복식을 보내고, 이 외 왕세자의 관복도 보내온다. 그러나 그 신에 관 해서는 언급이 없다. 석에 관한 비교적 상세한 사항 은 의종 때의『상정고금례(詳定古今禮)』에 나타난다. 이에 의하면 왕과 신하의 면복에 적석, 원유관복에 흑석을 신는다. 그리고 장식의 배색은 왕의 적석에서 만 확인되는데, 억과 준은 신울과 같은 적색이고 구 는 청색이다.27) 고대 문헌에서 '청색'으로 기록되는 경우 대개 밝은 청색이 아닌 흑색에 가까운 청색을 의미한다. 따라서 구에 청색을 썼다는 것은 흑색을 쓴 것과 같은 의미로 받아들일 수 있고, 이 경우 고 려시대 남자용 석의 배색에는 회차의 원칙이 일부 적용된 것으로 볼 수 있다.

조선시대에는 면복과 원유관복 모두 적석을 신고, 이는 왕, 왕세자, 왕세손 등에게 모두 공통되는 사항 이다. 고려시대부터 조선전기까지의 석은 고례서에 제시된 신목이 없는 형태가 아니라 화(靴)와 유사하 게 신목이 있는 형태이다. 이러한 형태는 송대에 관 원들이 예복에 화와 리(履)를 번갈아 신다가 양자를 결합하면서 시작된 것이다. 그런데 정조와 순조 연간 에 신목이 없어지기 시작하였고, 순조 이후부터 대한 제국까지는 고례처럼 신목이 없이 신울만 있는 형태 로 변화한다. 이렇게 신의 기본형태가 변하면서 장식 도 변형된다. 구(絇)와 억은 없어진다. 준(純)은 '도 리[回伊]'라는 명칭을 쓰기도 하는데, 영-정조대까 지의 신목이 있는 형태에서는 신의 중간에 해당하는 
발목 부분에 둘러지다가 신목이 사라진 순조 이후에 는 고례에서처럼 신 입구의 가장자리에 둘러진다. 재 료는 끈목이다. 또 같은 재료로 발등에 술을 달았고, 이 술은 음차(音借)하여 '수아(綬兒)'나 '소올(蘇匹)' 로 표기하였다. 기(棊)는 영자(繢子)로도 부르고, 영·정조 이전까지는 발목 부분에 있다가 영·정조 대부터 대한제국까지는 신 입구에 달리게 된다.

배색을 보면, 조선전기 태종3년(1403)에 명(明)에 서 보낸 적석에는 준을 소색(素色)으로 한다.28) 적색 에 소색을 배색했으므로 회차의 원칙이 적용되지 않 은 것이다.

조선후기에는 신목이 있을 때나 없을 때나 모두 적석에 아청색으로 도리와 술을 하고, 신울과 같은 대홍색으로 기(棊)를 한다.29) 기는 고례에서도 회차 와 수차의 배색원칙이 적용되지 않았는데, 조선시대 에도 마찬가지이다. 그러나 도리와 술을 장식한 아청 색은 청색을 약간 띠는 흑색이므로, 적석에 흑색 장 식은 고례와 같은 회차의 배색원칙을 적용한 것으로 볼 수 있다. 조선시대에 후기로 가면서 석의 기본형 태를 고례와 같은 형태로 회복하는데, 배색에 있어서 도 고례를 회복한 것으로 볼 수 있다.

대한제국시대 황제의 적석은 『대한예전(大韓禮典)』 의 제도30)와 유물 〈그림 3〉31)에서 모두 검은색[玄] 으로 술을 하고, 황색으로 도리를 한 것이 확인된다. 조선시대에는 도리와 술을 같은 재료에 같은 색으로 했는데, 대한제국에서는 도리와 술의 색을 다르게 한 것이다. 여기서 적석에 검은색 술 장식을 한 것은 조
선시대와 마찬가지로 회차의 원칙을 적용한 것으로 볼 수 있다. 그러나 도리에 황색을 쓴 것은 회차의 원칙과 무관한 것이다. 이 제도는 명(明)의 제도를 따른 것인데 32$)$, 명의 사료에서 도리를 황색으로 한 이유를 찾을 수 없어 그 배경은 파악하기 어렵다.

한편 황태자는 『대한예전』의 제도에서는 조선과 마찬가지로 도리와 술을 흑색으로 규정하였지만33), 실제 영친왕이 착용한 흑백사진 〈그림 4〉34)를 보면 도리의 색이 옅은색으로 나타나므로 황제와 같은 황 색을 쓴 것으로 보인다. 따라서 제도에서는 적석에 흑색 장식으로 하여 회차의 원칙을 적용하도록 했지 만, 실제는 이와 달랐을 것으로 보인다.35)

이상과 같이 남자용 석은 전반적으로 고례에서 제 시한 것처럼 엄격하게 회차의 원칙을 준용하지는 않 았던 것으로 보인다. 그러나 조선후기에는 기본형태 에서 고례를 회복함과 동시에 배색에 있어서도 고례 를 회복하여, 적석에 회차의 원칙을 따라 대방의 색 인 흑색으로 장식을 했음이 확인된다.

\section{2. 여자용}

고려시대 여자용 석은 말기에 왕비가 심청색 적의 와 함께 신은 청석에 관한 기록이 있다. 다만 신울이 청색이라는 점 외에 장식의 색은 언급이 없다.36)

조선시대에는 대삼제적의에 석을 신는데, 왕비와 대비는 적석이고 왕세자빈과 왕세손빈은 흑석이다. 모두 적의의 색을 따른 것인데, 대비는 자색 적의이

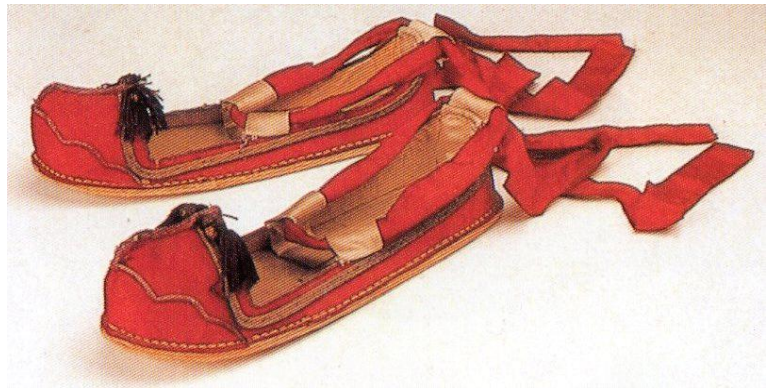

〈그림 3〉황제(추정) 적석

엘칸토박물관 소장

- 靴・鞋・履, p. 133

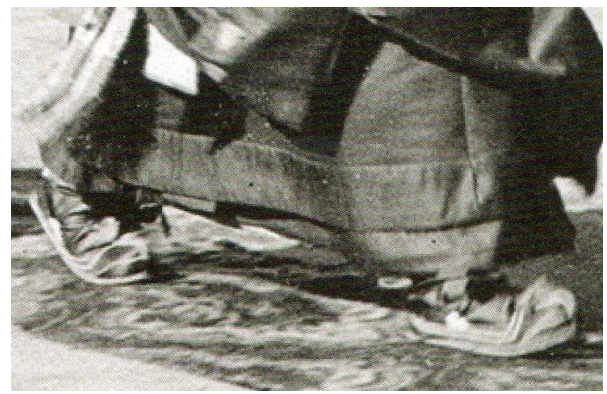

〈그림 4〉영친왕 면복의 적석 서울대학교박물관 소장

- 왕실문화도감, p. 56 
지만 그 신은 적석이다. 또 상례(言禮)의 습(襲)에 장삼(長衫)을 쓰는데, 조선전기에는 여기에 리(履)를 신기지만 1718 년 경종의 세자빈인 단의빈(端懿嬪) 부 터 석을 사용한다.37) 장삼과 함께 사용한 석은 각 신 분별로 적의의 색을 따른다. 예를 들어 왕비는 장삼 에 적석을 쓰고, 왕세자빈은 흑석을 쓰는 것이다.

여자용 석은 1600 년대 초반까지는 신목이 없는 형 태였다가 1600 년대 전반기에 남자용과 같은 신목이 있는 형태로 바뀌고, 다시 순조 이후 신목이 사라졌 을 것으로 추정된다. 배색은 왕비 적석에서 확인되는 데, 모단(冒䋿)으로 가선장식[緣飾](인원왕후와 정성 왕후의 『상례의궤』에서 이를 '환영(圆縜)'이라 하였 음)을 하였다.38) 모단은 검은색이다. 따라서 왕비 적 석의 배색은 남자용 적석과 마찬가지로 회차의 원칙 을 따랐음을 알 수 있다. 이는 고례에서 회차와 수차 를 적용시킴에 있어 남녀를 구분하지 않았던 전통을 이은 것이다.

대한제국시대에는 적석, 청석, 흑석 등이 사용된다. 적석은 명헌태후가 상례의 대렴(大斂)에 적의의 일 습으로 쓰고 또 습에 장삼과 함께 썼으며, 순명효황 후 민씨와 순헌황귀비 엄씨의 장례에 장삼과 함께 사용되었다. 청석은 황후와 황태자비가 심청색적의에 신었고, 또 순헌황귀비 엄씨가 원삼(圓衫)과 함께 신 기도 하였다. 흑석은 여흥부대부인 민씨가 노의(露 衣)와 함께 사용하였다. 이들 석의 배색은 문헌을 통 해서는 확인할 수 없고, 유물이 남아있는 황후와 황 태자비의 심청색적의 일습인 청석을 통해서 확인할 수 있다. 세종대학교박물관에 소장되어 있는 순정효 황후 윤씨의 청석 〈그림 5〉39)는 장식이 청현색인데
색이 바랜 것을 고려하면 본래 검은색이었을 것이다. 또 국립고궁박물관에 소장된 영친왕비의 청석〈그림 $6>40)$ 은 장식이 검은색이다. 청색 신울에 흑색 장식을 했으므로, 비방의 색끼리 배색하는 수차의 원칙을 따 른 것이다.

중국 역대 왕조에서 여자용 석의 배색 제도는 한 대부터 원대(元代)까지 기록에 나타나지 않는다.41) 그러다가 명에 이르러 아래와 같은 제도가 규정된다.

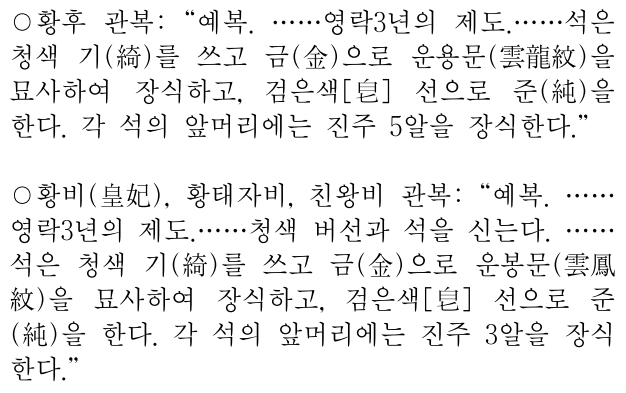
청색 기(綺)를 쓰고 금(金)으로 운용문(雲龍紋)을 묘사하여 장식하고, 검은색[包] 선으로 준(純)을 한다. 각 석의 앞머리에는 진주 5 알을 장식한다."

○ 황비(皇妃), 황태자비, 친왕비 관복: “예복. ….. 영락3년의 제도. .....청색 버선과 석을 신는다. $\cdots . .$. 석은 청색 기(綺)를 쓰고 금(金)으로 운봉문(雲鳳 紋)을 묘사하여 장식하고, 검은색[包] 선으로 준 (純)을 한다. 각 석의 앞머리에는 진주 3 알을 장식 한다."

○군왕비(郡王妃) 관복: “예복. …...영락 3 년의 제 도.…청색 버선과 석을 신는다. $. \cdots .$. 석은 청색 기 (綺)를 쓰고 금(金)으로 적문(翟紋)을 묘사하여 장식하고, 검은색[包] 선으로 준(純)을 한다. 각 석 의 앞머리에는 진주 3 알을 장식한다." 42$)$

황후부터 군왕비에 이르기까지 모두 청석에 흑색 으로 장식을 하도록 규정하였다. 대한제국의 복식제 도는 기본적으로 명의 제도를 따르는데, 여자용 석의 배색에 있어서도 명과 같게 규정한 것이다.

이렇게 명과 조선의 여자용 석에서 수차의 원칙을 따른 청색과 흑색의 배색은 고례와 다른 적용 방식이 다. 고례에서는 석과 구를 신의 등급에 따라 회차와

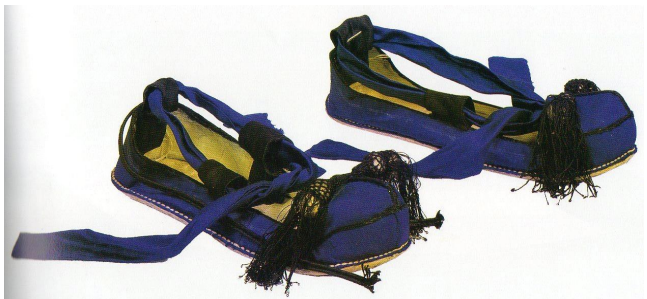

〈그림 4〉 영친왕비 청석

국립고궁박물관 소장

- 朝鮮朝後期 宮中服飾, D. 67

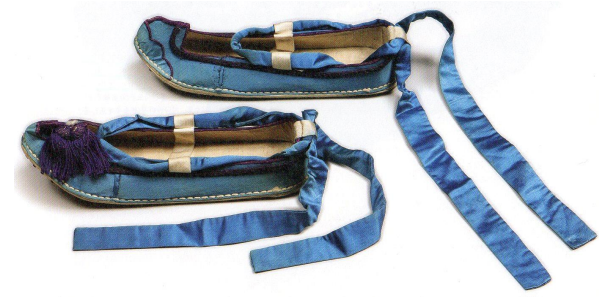

〈그림 3〉 순정효황후 청석

세종대학교박물관 소장

- 문화재대관, p. 55 
수차를 차별화시켜 적용시키기는 했으나 남녀에 따라 차별화시키지는 않았었다. 그러나 전통시대 남녀 관 념에서 남자를 위[上]-천(天)과 연계시키고 여자를 아래[下]-지(地)와 연계시키던 관념이 명대에 석에 적용되었고 이 규정이 대한제국에서도 준용되어, 남 자용 석에는 회차를 적용하고 여자용 석에는 수차를 적용하였다. 고례에서 신에 적용한 회차와 수차의 배 색원칙이 후대에 변용된 것을 확인할 수 있다.

\section{$\mathrm{V}$. 맺음말}

석에 적용된 배색원칙에 관해 살펴보았다. 연구결 과는 다음과 같다.

회차와 수차는 본래『주례』와『의례』등의 고례서 에서 면복의 상의와 하상에 무늬를 표현할 때의 배 색원칙을 제시한 것이다. 그림[繪]은 상(上)-천(天)양(陽)과 연계되므로 상의에 그림으로 무늬를 표현 하여 양을 상징하고자 하였고, 자수는 하(下)-지 (地)-음(陰) 과 연계되므로 하상에 자수로 무늬를 표 현하여 음을 상징하고자 하였다. 그리고 그림과 자수 로 무늬를 표현할 때는 임의로 색을 쓰는 것이 아니 라 일정한 배색원칙이 있다. 그림으로 무늬를 표현할 때의 배색원칙은 회차이고, 자수로 무늬를 표현할 때 의 배색원칙은 수차이다.

신목이 없이 신울만 있는 신을 고대인들은 석(舄) 과 구(侥)로 구별하였다. 구별 기준은 바닥의 구조인 데, 석은 바닥을 이중으로 하고 그 사이에 나무를 대 었고 구는 바닥을 홑으로 하였다. 이 석과 구는 또 등급의 구별이 있어서 석의 등급이 높고 구의 등급 이 낮다. 때문에 고대인들이 각종 상황에 착용한 예 복에는 그 중요도에 따라 등급이 높은[上] 옷에는 석을 신고, 등급이 낮은[下] 옷에는 구를 신었다.

석과 구의 등급 구별은 신울과 장식(구(絇), 억 (繶), 준(純))의 배색에도 영향을 미쳤다. 등급이 높 은 신인 석은 상의에 무늬를 표현하는 방식인 회차 의 원칙을 적용하였고, 등급이 낮은 신인 구는 하상 에 무늬를 표현하는 방식인 수차의 원칙을 적용하였 다. 이를 통해 석에는 양의 상징성을, 구에는 음의 상징성을 함유시키고자 하였다.
회차와 수차는 천지와 오방의 색을 어떻게 쓸 것 인가에 관한 원칙을 제시한 이론이다. 천-현, 지-황, 동-청, 남-적, 서-백, 북-흑, 중-황의 색들을 회차에 서는 반대방향[對方] 의 색끼리 배색하고, 수차에서는 옆에 있는 방향[능ㄱㅇㅢ 색끼리 배색한다. 즉 회차에 서는 현-황, 청-백, 적-흑으로 배색한다. 때문에 적석 에는 구, 억, 준의 장식을 흑색으로 하고, 백석에는 청색, 흑석에는 적색, 현석(玄舄)에는 황색, 청석에는 백색으로 장식을 한다. 또 수차에서는 청-적, 적-백, 백-흑, 흑-청으로 배색하고, 또 상생(相生)의 관념을 적용시키면 이 외에 황-백의 배색이 생긴다. 때문에 황구(黃㞛)에는 장식을 백색으로 하고, 백구(白猸)에 는 흑색, 흑구(黑屨)에는 청색으로 장식을 한다.

고례(古禮)에서 회차와 수차의 원칙을 적용함에 있어 석과 구의 등급에 따른 차별은 나타나지만 남 녀에 따른 차별은 나타나지 않는다. 남녀 모두 석에 는 회차를, 구에는 수차를 적용한다.

우리나라 석에서 회차와 수차는 고례의 원칙대로 적용된 면도 있지만 그와 달리 변용된 면도 나타난다.

남자용은 고려시대 적석에 회차 원칙이 일부 장식 에 적용되기도 했으나 장식 전체에 적용되지는 않았 다. 조선전기 적석에는 회차나 수차의 원칙이 적용되 지 않았고, 후기에는 형태에서 신목이 없는 고례의 형태로 회복함과 동시에 배색에서도 장식을 흑색으 로 하여 고례대로 회차의 원칙을 적용하였다. 대한제 국 황제 적석에서는 술에 회차의 원칙이 적용되었으 나 도리[回伊]에는 적용되지 않았고(명의 제도를 따 른 것임), 황태자 적석은 제도에서는 회차의 원칙을 적용하여 흑색으로 했으나 실제 착용된 석은 황제와 같은 것으로 하여 제도대로 따르지 않는다. 따라서 남자용 석에서는 조선후기에 고례가 준용되었다.

여자용은 조선후기에 남자용과 마찬가지로 적석에 흑색으로 장식을 하여 회차의 원칙을 적용하였다. 그 러나 대한제국시대에 황후와 황태자비가 신은 청석 에는 흑색으로 장식을 하여, 수차의 원칙을 적용한 것이 확인된다. 여자용 석에 수차를 적용한 것은 고 례에 남녀를 차별화하지 않던 원칙에서 변용된 양상 이고, 이는 명에서 유래한 것이다. 


\section{참고문헌}

1）國朝五禮儀, 卷1 吉禮 “祭服圖說”：“繪, 陽事也, 故在衣 繡, 陰功也, 故在裳."

2) 최규순(2013), 조선시대 석(舄) 연구, 복식 63-2, pp. 144-161; 최연우(2013), 대한제국시대 석(舄)의 고찰 및 한국 석의 형태적 특징의 유래, 복식 $63-8, \mathrm{pp}$. 125-142.

3）崔圭順(2007)，中國歷代常王冕服研究，上海：東華大學 校出版社, p. 207.

4）周禮，侥人：“侥人掌王及后之服侥，爲赤舄・黑舄，赤

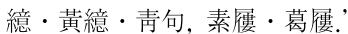

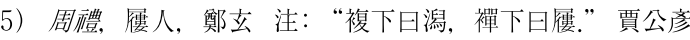
疏: “下謂底, 複, 重底. 重底者名曰舄, 襌底者名曰侥也.”

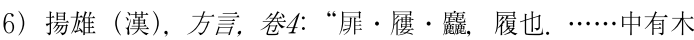
者謂之複潟, 自闗而東複履.”

7）崔豹（晉)，古今注 (1998, 沈陽：遼寧教育出版社)：“潟, 以木置履下, 幹臘不畏泥濕也.”

8）張惠言（淸），儀體圖，“舄”。

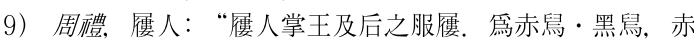

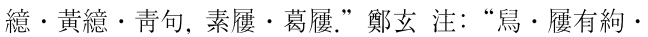
有繶・有純者，飾也.”賈公彥 疏：“言繶是牙底相接之 縫, 緅條於其中. 言絇謂㞛頭以條鷂鼻. 純謂以條爲口緣.”

10）儀禮，士冠禮：“霓，夏用葛，玄端黑侥，靑絇・繶・純.” 鄭玄 注: “絇之言拘也, 以爲行戒, 狀如刀衣鼻, 在偖頭 繶, 縫中紃也. 純, 緣也.”(『周禮』「侥人」의 정현 주에 도 같은 내용 있음); 禮記, 玉藻: “童子不表不帛, 不

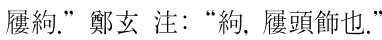

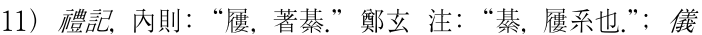
禮，士喪禮：“組綦系於踵.”賈公彥 疏: “則拲當屬於跟 後, 以兩端向前, 與絇相連於脚跱之上合結之, 名爲繫於 踵也.” 儀軆，士衰禮：“乃侥基結於跗。”鄭玄 注：“跗， 足上也.”

12) 互言은 한문의 서술 원칙으로, 문장이 번잡해지는 것 을 위해 반복되는 같은 뜻의 글자를 생략하는 것이다. 따라서 해당 문구를 이해할 때는 하나의 한자를 앞뒤 내용에 서로 연계시킬 필요가 있다. 「구인」經文에서 적석과 흑석의 장식으로 적색과 황색의 繶 및 청색 句[絇]만 언급했지만, 여기에는 적색 억, 구, 준, 황색 억, 구, 준, 청색 억, 구, 준이 각각 포함된다. 이를 정 현 注와 가공언 疏에서 설명하고 있다.

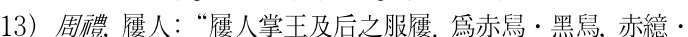
黄繶・青句, 素屦・葛屠.”鄭玄 注: “王吉服有九, 舄有 三等，赤舄爲上，冕服之舄。……有白舄・黑舄。王后 吉服六, 惟祭服有舄。玄舄爲上, 禕衣之舄也。有靑 舄・赤舄。鞠衣以下皆嘚耳。句當爲絇, 聲之誤也. 絇・ 繶・純者同色，今云赤繶・黄繶・青絇，雜互言之，明 舄・㞛衆多, 反覆以見之. 凡舄之飾, 如繢之次. 赤繶者, 王黑舄之飾，黃繶者，王后玄舄之飾，靑絇者，王白舄之 飾。言繶必有絇・純，言絇亦有繶・純，三者相將。王及 后之赤舄皆黑飾, 后之青舄白飾。 凡侥之飾, 如綉次也,

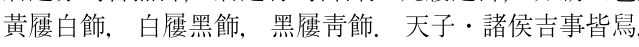
其餘惟服冕衣翟著舄耳，士節弁纁桡，黑絇・繶・純，尊 祭服之侥飾, 從繢也.”
14）周禮, 司服：“王之吉服, 祀吴天上帝, 則服大表而冕, 祀 五帝亦如之, 享先王則衰冕, 享先公. 䭌射則驚冕, 祀四 望・山川則委冕, 祭社稷・五祀則希冕, 祭群小祀則玄冕. ……兵事, 韋弁服. 視朝, 則皮弁服. 凡甸, 冠弁服.”

15）周禮，內司服：“內司服掌王后之六服, 褘衣, 揄狄, 關狄, 鞠衣, 展衣, 緣衣, 素沙,”鄭玄 注: “鄭司農云：‘……展 衣, 白衣也。……鞠衣, 黄衣也.……玄謂……合世有圭衣 者, 盖三翟之遺俗. 鞠衣, 黃, 桑服也. ……此緣衣者, 實

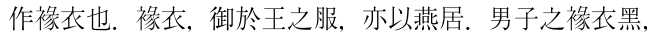
則是亦黑也. 六服備於此矣. ……以下推次其色, 則闕狄 赤, 揄狄青, 褘衣玄."

16) 玄色과 黑色: 두 색은 모두 '검은색'으로 번역된다. 다 만 검은색을 대표하는 단어가 '흑색'이라면, '현색'은 붉은색을 약간 띄는 검은색을 나타낸 漢許慎의『說文 解字』(卷4下)에서 "검은색이지만 적색이 있는 것이 현색이다(黑而有赤色者爲玄)”라 하였다. 구체적으로, 현색은 붉은색과 검은색 염료에 총6번을 담가서 얻어 지는 색으로 추정된다.『爾雅』「釋器」(卷6)에서 “한 번 염색한 것을 縓, 두 번 염색한 것을 楨, 세 번 염 색한 것을 緟이라 한다(一染謂之縓, 再染謂之楨, 三染 謂之緟)”라 하였다. 또『周禮』「鍾氏」의 “세 번 넣으 면 緟이 되고, 다섯 번 넣으면 緅가 되고, 일곱 번 넣 으면 紉가 된다(三人謂緟, 五入爲緅, 七人爲緇)”라는 經文에 대해 鄭玄은 “훈색을 염색하는 것은 세 번 넣 어서 완성된다. 또 흑색으로 두 번을 염색하면 緅가 된다. ……또 흑색으로 두 번을 다시 염색하면 마침 내 緇가 완성된다. ……무릇 현색이라는 것은 추색과 치색의 사이에 있는 것으로, 그것은 여섯 번 넣는 것 인가(染繮者, 三人而成. 又再染以黑, 則爲緅. ……複 再染以黑, 乃成緇矣. ……玄色者, 在緅 - 緇之間, 其 六入者與?)라 하였고, 賈公彥은 “훈색에 만일 적색 염료를 넣으면 朱가 된다. 만일 적색이 아닌 흑색 염 료에 넣으면 紺이 된다. 만일 다시 이 감색을 흑색 염료에 넣으면 緅가 되니, 여기서 다섯 번 넣으면 추 색이 된다는 것이 이것이다. …..만일 다시 이 추색 을 흑색 염료에 넣으면 玄이 되므로, 여섯 번 넣어서 현색이 된다. ……다시 이 현색을 흑색 염료에 넣으 면 일곱 번을 넣어서 緇라 하는 것이다(緟若入赤汁, 則篇朱, 若不入赤而黑汁, 則爲紺矣. 若更以此紺入黑,

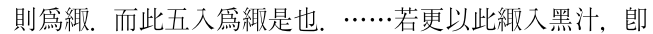
営玄, 則六入爲玄。……更以此玄入黑汁, 則名七入爲緇 矣).”라 하였다. 종합하면, 검은색을 얻고자 할 때 세 번까지는 붉은색 염료에 담그고, 네 번째부터 검은색 염료에 담근다. 붉은색에 1 번을 담그면 縓, 2 번은 楨, 3 번은 緟이 되고, 이어 4 번째에 검은색 염료에 담그 면 紺, 5 번째에 역시 검은색 염료에 담그면 緅, 6 번째 에 검은색 염료에 담그면 玄, 7 번째에 검은색 염료에 담그면 緇가 된다. 현색은 붉은색 염료에 3 번, 이어 검은색 염료에 3 번을 넣어 완성된다. 위『주례』의 정 현과 가공언의 주석에서 검은색 염료를 대표하는 한 자로 '黑'을 쓰고 있고, '玄”은 이 흑색 염료에 담가서 얻어지는 하나의 색으로 말한다. 따라서 '흑'이 검은 색을 대표하고 '현'은 그 검은색 중의 하나임을 알 수 있다. 한편 오방과 天地의 색을 표현함에 있어, 본문

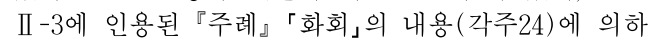


면 오방색에서는 '흑색', 天을 나타내는 색에서는 '현 색'이라 하는 것이 기본임을 알 수 있다.

17) 각주 15) 참조.

18）儀禮，士冠禮：“玄端黑屣，青絇・繶・純，純博寸，素積

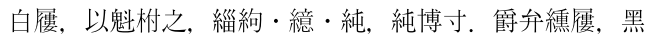
絇・繶・純, 純博寸。”

19）儀軆，士冠禮，鄭玄 注：“節弁屢以黑爲飾，爵弁尊，其

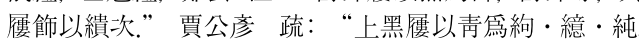
白霋以黑爲絇・繶・純, 則白與黑, 黑與青爲紼次之事 也. 今次節弁緟㞛, 緟, 南方之色赤, 不以西方白爲絇 . 繶・純, 而以北方黑爲絇・繶・純者, 取對方繢次爲飾, 擧舄者, 尊節弁是祭服, 故飾與舄同也.” 번역 중 “석이 배색과 같은 것인데’의 원문은 “擧舄者”이다. 그런데 ‘擧舄者' 그대로 번역할 경우 의미가 통하지 않고, 이 에 대해 李學勤 主編의 『儀禮注疏』 표점본(1999. 北 京: 北京大學出版社)에서 “與舄同”의 오기일 가능성을 제시하였다. 이에 근거해 번역한 것이다.

20)『向書』「虞書·益稷」에서는 면복의 12 장문에 관한 언 급에서 ‘會[繪]’라 하였고,『禮記』「玉藻」정현 注에서 는 “繢는 會로도 쓴다(繢, 或作會)”라 하였다.

21）禮記, 禮運：“初畫曰畫, 成文曰繢."

22）經國大典, 卷1, 吏典 “雜職・圖畫署”.

23）周禮，畫繢，賈公彥 疏：“畫・繢並言者, 言“畫”是總語, 以其繢・紼皆須畫之. ……繣亦須畫, 乃刺之, 故畫 繡二工, 共其職也."

24）周禮，畫繢：“甾繢之事，雜五色，東方謂之青，南方謂之 赤, 西方謂之白, 北方謂之黑, 天謂之玄, 地謂之黄. 青與 白相次也, 赤與黑相次也, 玄與黄相次也, ”鄭玄 注: “此 言畫繢六色所象及布彩之第次, 繢以爲衣.”賈公彥 疏: “言”繢”, 則据對方而言, 自“東方”已下是也。……青與白 相次”已下, 論繢於衣, 爲對方之法也.”

25）周禮，畫繢：“青與赤謂之文, 赤與白謂之章, 白與黑謂之 䊇, 黑與青謂之糖, 五采備謂之繣, ”鄭玄 注: “此言刺紼

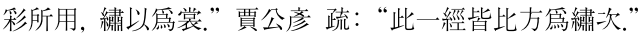

26）周禮，畫繢，賈公彥 疏：“衣在上，陽，陽主輕浮，故畫 之. 裳在下, 陰, 陰主沉重, 故刺之也.”

27）高麗史，参72，舆服志1 冠服：“(王)祭服，……毅宗朝詳 定……衰冕九旒……赤舄, 赤繶. 赤純・靑絇・基帶.”

28）太宗實錄 태종3년 10월 27일(辛未): “大紅紵絲舄一雙 【上帶素綵線條, 青熟綵線結底】” 여기서 “위에 소색 견사로 만든 끈목을 두른다”라고 하였는데, 이는 純을 의미한다.

29）晌方定例, 卷2, 別例 上：“赤舄. 表大紅廣的. ○内拱白 羅。昌白羅。縜子次大紅廣的。回伊蘇兀及昌訥非 音鴉靑眞絲。袙白正布染尺. 縫作白絲武錢。”; 國朝喪禮 補編圖說, “大斂”：“【圭以下至赤舄用平日所御者】…… 舄 表用紅熟綃 裏白熟綃 純及綬兒【郎蘇元】用鴉青眞 綵 左右及後從純側綴白綃小彄子 用紅綃爲基貫彄而結之.”

30）大韓禮典，卷4, 祭服圖說“皇帝冕服”：“舄：舄以赤䋄爲 之, 黄條緣, 玄縜結。”

31) 단국대학교 석주선기념박물관 (2004), 靴·鞋・履, 서 울: 단국대학교 석주선기념박물관, p. 133

32）大明會典, 爸 60 , 禮部 18 , 冠服1, “皇帝冕服”: “嘉靖八年 定……赤舄, 黄條緣, 玄縜結。”
33）大韓禮典, 卷4, 祭服圖說 “皇太子冠服”: “舄以赤䋄爲之, 黑鉤純, 黑飾舄首."

34) 국립고궁박물관 (2012), 왕실문화도감-조선왕실복식-, 서울: 국립고궁박물관, p. 56.

35) 이상 고려시대부터 대한제국시대까지의 신울과 장식 간의 배색에 관한 내용은 머리말에 제시한 두 편의 선행연구(최규순, $O p$. cit., pp. 144-161; 최연우, $O p$. cit., pp. 125-142)에 근거해 정리하였다. 아래 여자용 석의 배색도 마찬가지이다.

36）高麗史，卷72，舆服志 1 冠服：“王妃冠服. 恭堭王十九年 五月。太祖高皇帝孝慈皇后賜冠服……䨼衣青質, 紼翟九 等, ……青舄.”

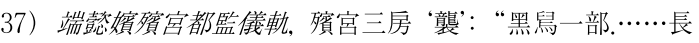
衫."

38）國朝䒼禮補編圖說, “襲”：“【内喪所用】舄, 表用紅廣織 【小內高冒紘】, 裏白羅・糊紙爲之, 緣飾用冒緞, 以紅 綠絲作花三瓣, 緅於當跗【足背】處,"

39) 문화재청 (2006), 문화재대관-중요민속자료(2)복식 - 자 수편, 대전: 문화재청 무형문화재과, p. 55.

40）金英淑（2002），朝鮮朝後期 宮中服飾，서울：新西, p. 67.

41）隋書, 卷11, 禮儀志6：“(北周)皇后及諸侯夫人之服, 皆 舄・履. 三妃·三公夫人已下, 翟衣則舄, 其餘皆喉,”; 隋書, 卷12, 禮儀志7: “(개황연간) 皇后褘衣, 【深靑織

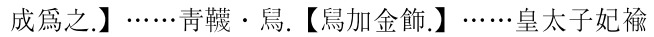

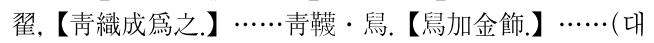
업원년) 皇后……禕衣, 深青質, ……靑茂·舄, 舄以金 飾, ……皇太子妃, 服褕翟之衣, 青質, ……青舄, 舄加金 飾.”; 舊唐書, 忩45, 舆服志：“武德令. 皇后 ……褘衣 ……其衣以深青織成営之, ……青荗・舄.【舄加金飾 .】……皇太子妃服 ……褕翟【青織成爲之.】……青 䪄・舄.【舄加金飾.】”; 宋史, 悉151, 舆服志3: “后妃

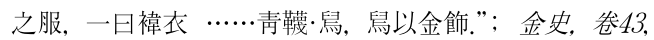
與服志 中: “皇后冠服, ……褘衣, 深青羅織成, ……舄, 以青羅製, 白綾裏, 如意頭, 明金·黃羅準上用, 玉鼻仁 眞珠裝, 緅繫帶."

42）大明會典, 卷60, 冠服1, “皇后冠服”：“禮服。……永樂三 年定……舄用靑綺, 飾以描金雲龍文, 㿝線純, 每舄首加 珠五顆”; “皇妃冠服”, “皇太子妃冠服”, “親王妃”: “禮服. ……永樂三年定……青䗃・舄 ……舄用青綺, 飾以描金 雲鳳文, 㿝線純, 每舄首加珠三顆.”; “郡王妃冠服”: “禮 服。……永樂三年定 ……青鞮・舄……舄用靑綺, 飾以 描金翟文, 㿝線純, 每舄首加珠三顆.” 